\title{
Karyotype of cryopreserved bone marrow cells
}

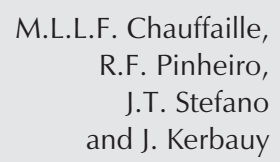

Disciplina de Hematologia e Hemoterapia, Escola Paulista de Medicina, Universidade Federal de São Paulo, São Paulo, SP, Brasil

\author{
Correspondence \\ M.L.L.F. Chauffaille \\ Disciplina de Hematologia e \\ Hemoterapia, EPM, UNIFESP \\ Rua Botucatu, 740, 3o andar \\ 04023-900 São Paulo, SP \\ Brasil \\ Fax: +55-11-5571-8806 \\ E-mail: chauffaill@hemato.epm.br \\ Publication supported by FAPESP. \\ Received August 8, 2002 \\ Accepted April 9, 2003
}

\begin{abstract}
The analysis of chromosomal abnormalities is important for the study of hematological neoplastic disorders since it facilitates classification of the disease. The ability to perform chromosome analysis of cryopreserved malignant marrow or peripheral blast cells is important for retrospective studies. In the present study, we compared the karyotype of fresh bone marrow cells (20 metaphases) to that of cells stored with a simplified cryopreservation method, evaluated the effect of the use of granulocyte-macrophage colony-stimulating factor (GM-CSF) as an in vitro mitotic index stimulator, and compared the cell viability and chromosome morphology of fresh and cryopreserved cells whenever possible (sufficient metaphases for analysis). Twenty-five bone marrow samples from 24 patients with hematological disorders such as acute myeloid leukemia, acute lymphoblastic leukemia, myelodysplastic syndrome, chronic myeloid leukemia, megaloblastic anemia and lymphoma $(8,3,3,8,1$, and 1 patients, respectively) were selected at diagnosis, at relapse or during routine follow-up and one sample was obtained from a bone marrow donor after informed consent. Average cell viability before and after freezing was 98.8 and $78.5 \%$, respectively $(\mathrm{P}<0.05)$. Cytogenetic analysis was successful in $76 \%$ of fresh cell cultures, as opposed to $52 \%$ of cryopreserved samples $(\mathrm{P}<$ 0.05). GM-CSF had no proliferative effect before or after freezing. The morphological aspects of the chromosomes in fresh and cryopreserved cells were subjectively the same. The present study shows that cytogenetic analysis of cryopreserved bone marrow cells can be a reliable alternative when fresh cell analysis cannot be done, notwithstanding the reduced viability and lower percent of successful analysis that are associated with freezing.
\end{abstract}

The analysis of chromosomal abnormalities is extremely important for the diagnosis of hematological neoplastic disorders since it facilitates the classification of the disease as recommended by the World Health Organization Classification of Tumors of Hematopoietic and Lymphoid Tissues (1). In
Key words

- Cryopreservation

- Karyotype

- Bone marrow cells

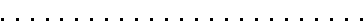

addition, it is fundamental for prognosis and helps monitoring residual disease and the occurrence of relapse or clonal evolution.

Cytogenetic studies involve the examination of mitotic cells and therefore require spontaneously dividing bone marrow cells or even circulating blasts in peripheral blood. 
However, karyotype results cannot be obtained in all cases since the main problem in chromosomal analysis and karyotyping is a low mitotic index in some samples or fuzzy chromosomes sometimes not analyzable. Many efforts have been made in order to increase the mitotic index using conditioned media derived from solid tumor cell lines that contain growth factors, granulocytemacrophage colony-stimulating factor (GMCSF) or recombinant interleukin 3, although with poor results $(2,3)$.

In fact, the ability to perform chromo-

Table 1. Patient diagnosis and mitotic index data obtained for each pre- and postfreezing culture and cryopreservation period.

\begin{tabular}{|c|c|c|c|c|c|c|}
\hline \multirow[t]{4}{*}{ Case } & \multirow[t]{4}{*}{ Diagnosis } & \multicolumn{4}{|c|}{ Mitotic index } & \multirow{4}{*}{$\begin{array}{l}\text { Duration of } \\
\text { cryopreservation }\end{array}$} \\
\hline & & \multirow{2}{*}{\multicolumn{2}{|c|}{$\frac{\text { Pre-freezing }}{\text { GM-CSF }}$}} & \multirow{2}{*}{\multicolumn{2}{|c|}{$\frac{\text { Post-freezing }}{\text { GM-CSF }}$}} & \\
\hline & & & & & & \\
\hline & & - & + & - & + & \\
\hline 1 & CML & 6.3 & 7.0 & 2.3 & 3.0 & 12 days \\
\hline 2 & $\mathrm{CML}$ & 5.3 & 7.3 & 3.0 & 2.0 & 16 days \\
\hline 3 & BM donor & 4.7 & 6.7 & 1.7 & 2.0 & 35 days \\
\hline 4 & $\mathrm{CML}$ & 0 & 2.0 & 0.3 & 0.3 & 45 days \\
\hline 5 & AML-M4 & 0.7 & 0.3 & 0 & 0 & 3 months \\
\hline 6 & AML post-BMT* & 1.0 & 1.3 & 1.0 & 1.7 & 3 months \\
\hline 7 & MDS & 1.3 & 3.0 & 0.3 & 1.0 & 3 months \\
\hline 8 & ALL-T* ${ }^{*}$ & 5.0 & 6.0 & 0 & 0 & 3 months \\
\hline 9 & ALL-T & 1.0 & 2.3 & 0.7 & 0.3 & 3 months \\
\hline 10 & AML-M2* & 0.7 & 2.3 & 0 & 0 & 3 months \\
\hline 11 & Lymphoma & 0.3 & 0.3 & 0.3 & 0 & 3 months \\
\hline 12 & MDS & 0 & 0 & 0 & 0 & 3 months \\
\hline 13 & AML-M2 & 1.7 & 1.3 & 0 & 0.3 & 3 months \\
\hline 14 & AML-M7 & 0.3 & 1.7 & 1.3 & 2.3 & 3 months \\
\hline 15 & CML-BC & 0 & 0 & 0 & 0 & 3 months \\
\hline 16 & $\mathrm{CML}$ & 3.7 & 9.3 & 0.3 & 2.3 & 3 months \\
\hline 17 & ALL in remission & 0.7 & 2.7 & 0 & 0 & 3 months \\
\hline 18 & $\mathrm{CML}$ & 0.7 & 3.0 & 0.7 & 0 & 3 months \\
\hline 19 & Megaloblastic anemia & 1.3 & 3.0 & 3.0 & 1.3 & 4 months \\
\hline 20 & $\mathrm{AML}$ in remission & 0.7 & 2.0 & 0.0 & 0.3 & 4 months \\
\hline 21 & MDS & 1.7 & 3.0 & 0.3 & 0.7 & 4 months \\
\hline 22 & AML-M3 & 1.0 & 1.3 & 0 & 0 & 4 months \\
\hline 23 & AML-M2* & 1.0 & 2.3 & 0.3 & 0.3 & 4 months \\
\hline 24 & $\mathrm{CML}$ & 1.7 & 2.7 & 0 & 0.3 & 4 months \\
\hline 25 & $\mathrm{CML}$ & 4.0 & 2.7 & 0.3 & 0.3 & 4 months \\
\hline
\end{tabular}

Bone marrow cells were cultured in the presence $(+)$ or absence $(-)$ of $0.1 \mu \mathrm{g} / \mathrm{ml}$ granulocyte-macrophage colony-stimulating factor (GM-CSF). Mitotic index data are reported as the mean of three independent determinations. ALL, acute lymphoblastic leukemia; $\mathrm{AML}$, acute myeloid leukemia; BC, blast crisis; BM, bone marrow; BMT, bone marrow transplantation; $\mathrm{CML}$, chronic myeloid leukemia; MDS, myelodysplastic syndrome. ${ }^{*}=$ Relapse some analysis of cryopreserved malignant marrow or peripheral blast cells is important for retrospective studies or for storing additional material. This procedure could even provide enough time to determine a final morphological or immunophenotypic diagnosis of disease subtype while chromosome analysis is performed and could contribute to the decision about patient treatment and care. But the most important feature is that frozen cells are easily transported from remote facilities to experienced centralized cytogenetic laboratories for more detailed chromosomal analysis.

Reports that describe culturing of cryopreserved cells are helpful but show that the procedure is not as good as culturing fresh samples (2-4). The use of thawed cryopreserved cells has gained wide acceptance in routine clinical practice and in many areas of research such as immunohematology, transplantation and molecular biology (5).

The aim of the present study was to compare the karyotype of fresh bone marrow cells and cells preserved with a simplified cryopreservation method and to evaluate the effects of the use of GM-CSF as an in vitro mitotic index stimulator.

Twenty-five bone marrow samples from 24 patients with hematological disorders were selected at diagnosis, at relapse or during routine follow-up and one sample was obtained from a bone marrow donor after informed consent. Table 1 shows the diagnosis by FAB (6) and REAL (7) classification and the stage of the disease at the time of sample collection.

Fresh bone marrow cells were isolated with a Ficoll-Hypaque (Sigma, St. Louis, MO, USA) gradient and divided into two parts, one for cryopreservation and the other for fresh short-term cell culture.

The cells were cultivated as previously reported for chromosome analysis (8). Briefly, the cells were separated into two short-term cultures with $7 \mathrm{ml}$ RPMI 1640, $\mathrm{pH} 7.0,3 \mathrm{ml}$ fetal calf serum (Sigma), $100 \mu 1$ 
L-glutamine (2 mM, Synthy ${ }^{\circledR}$, São Paulo, $\mathrm{SP}$, Brazil) and incubated for $24 \mathrm{~h}$ at $37^{\circ} \mathrm{C}$. Seven microliters GM-CSF (100 ng/ml) $\left(\right.$ Leucomax $^{\circledR}$, Sandoz S.A., Basel, Switzerland) was added to one of the culture flasks for $24 \mathrm{~h}$ (culture B). Colcemid $(50 \mu \mathrm{l})$ was added to both culture flasks for the final 30 min, followed by $75 \mathrm{mM} \mathrm{KCl}$ at room temperature for 20 min and Carnoy's fixative for 5 min, four times. Slides were prepared and submitted to $G$ banding and whenever possible at least 15 metaphases were analyzed (range: 0-38) and the abnormalities described according to ISCN 1995 (9).

The cryopreservation method was the same as used by Zaroulis (10). Cells were cryopreserved in Normosol R (Abbott Laboratories, Chicago, IL, USA) with $12 \%$ hy- droxyethyl starch (Sigma), 8\% human serum albumin and 10\% dimethylsulfoxide (DMSO; Sigma). This cryoprotectant solution was added to bone marrow cells at a final concentration of $6 \%$ hydroxyethyl starch, $4 \%$ human serum albumin and 5\% DMSO. The vials were frozen at $-80^{\circ} \mathrm{C}$ and stored for 12 , 16,35 and 45 days in 4 cases, and at least 3 months in 21 cases. After the freezing period, the cells were rapidly thawed in a $37^{\circ} \mathrm{C}$ water bath and diluted with RPMI 1640 medium corresponding to three times the total bone marrow volume. Two cultures were then set up exactly the same way as for fresh cells. Cell viability was tested in all samples before and after freezing and the method described by Regidor et al. (11) was used to compare the results. Statistical analysis was

\begin{tabular}{|c|c|c|c|c|}
\hline Case & Pre-freezing & $\begin{array}{l}\text { No. of metaphases } \\
\text { obtained }\end{array}$ & Post-freezing & $\begin{array}{c}\text { No. of metaphases } \\
\text { obtained }\end{array}$ \\
\hline 1 & $46, X X, t(9 ; 22)(q 34 ; q 11)$ & 15 & $46, X X, t(9,22)(q 34 ; q 11)$ & 6 \\
\hline 2 & $46, X X, t(9 ; 22)(q 34 ; q 11)$ & 15 & $46, X X, t(9,22)(q 34 ; q 11)$ & 7 \\
\hline 3 & $46, X Y$ & 13 & $46, X Y$ & 7 \\
\hline 4 & $46, X Y, t(9 ; 22)(q 34 ; q 11)$ & 13 & No result & 4 \\
\hline 5 & No result & 9 & No metaphase & 0 \\
\hline 6 & No result & 36 & No result & 10 \\
\hline 7 & $46, X X$ & 15 & No result & 16 \\
\hline 8 & $\begin{array}{l}46, X X / 49, X X,+11,+19+21 / 50 \\
X X,+11,+19,+20,+21\end{array}$ & 4 & No metaphase & 0 \\
\hline 9 & $46, X Y, t(1 ; 7)(p 32 ; q 35),+11(p 11)$ & 11 & $46, X Y, t(1 ; 7)(p 32 ; q 35)+11(p 11)$ & 6 \\
\hline 10 & No result & 38 & No result & 10 \\
\hline 11 & $45, X X,-8,-22,+\operatorname{mar}$ & 6 & No result & 5 \\
\hline 12 & No metaphase & 0 & No metaphase & 0 \\
\hline 13 & $45, X,-Y, t(8 ; 21)(q 22 ; q 22)$ & 12 & No result & 7 \\
\hline 14 & No result & 24 & $46, X X$ & 15 \\
\hline 15 & No metaphase & 0 & No result & 7 \\
\hline 16 & $46, X Y, t(9 ; 22)(q 34 ; q 11)$ & 16 & $46, X Y, t(9 ; 22)(q 34 ; q 11)$ & 11 \\
\hline 17 & $46, X Y$ & 10 & $46, X Y$ & 8 \\
\hline 18 & $46, X Y, t(9 ; 22)(q 34 ; q 11)$ & 15 & $46, X Y, t(9 ; 22)(q 34 ; q 11)$ & 10 \\
\hline 19 & $46, X X$ & 10 & $46, X X$ & 10 \\
\hline 20 & $46, X Y$ & 10 & $46, X Y$ & 8 \\
\hline 21 & $46, X X$, del (11)(q23) & 15 & $46, X X, \operatorname{del}(11)(q 23)$ & 13 \\
\hline 22 & $46, X Y, t(15 ; 17)(q 22 ; q 12)$ & 11 & No result & 3 \\
\hline 23 & $\begin{array}{l}47, X Y,+d m / 46, X Y,-7 \\
+\operatorname{der}(1 ; 7)(q 10 ; p 10)\end{array}$ & 7 & No result & 8 \\
\hline 24 & $46, X X, t(9,22)(q 34 ; q 11)$ & 10 & $46, X X, t(9,22)(q 34 ; q 11)$ & 8 \\
\hline 25 & $46, X Y, t(9,22)(q 34 ; q 11)$ & 10 & $46, X Y, t(9,22)(q 34 ; q 11)$ & 8 \\
\hline
\end{tabular}

At least 15 metaphases were analyzed (range: 0-38). "No result" indicates a result not obtained due to poor morphology or paucity of metaphases. "No metaphase" indicates a complete absence of metaphases. 
performed by the Student $t$-test and paired $t$ test with a confidence interval of $5 \%$ $(\mathrm{P}<0.05)$.

For evaluation of cell proliferation, mitotic index was calculated as reported by Tsuchiya et al. (12). Three slides from each culture were prepared for this scoring. Cytogenetic analysis was successful in $76 \%$ of fresh cell cultures. In the remaining $24 \%$, results could not be obtained due either to poor banding or fuzzy chromosomes, while results were obtained for $52 \%$ of cryopreserved samples $(\mathrm{P}<0.05)$. The mitotic index for fresh cultures stimulated with GM-CSF did not differ from that for cultures cryopreserved with GM-CSF $(\mathrm{P}=0.08)$, indicating that GM-CSF did not exert a proliferative effect on these cells (Table 1). In addition, there was no difference between cultures A and $\mathrm{B}$ (with and without GM-CSF) with respect to mitotic index. The morphological aspect of the chromosomes in fresh and cryopreserved cells was subjectively the same. Chromosomal abnormalities were the same in both cultures (Table 2). There was a significant difference in mitotic index between pre-freezing and post-freezing A cultures $(\mathrm{P}=0.007)$ and between pre-freezing and post-freezing $\mathrm{B}$ cultures $(\mathrm{P}=0.000)$, showing that the mitotic index was reduced by cryopreservation.

The average cell viability before and after freezing was 98.8 and $78.5 \%$, respectively $(\mathrm{P}<0.05)$. The average frozen cell concentration was $25 \times 10^{6}$ cells $/ \mathrm{ml}$ and the average volume was $12.7 \mathrm{ml}$ (range: 1.2-38 $\mathrm{ml})$. There was no correlation between disease and viability.

Freezing is an insult to the cell and the physical disruption that takes place leads to intracellular chemical changes (13). The cryopreservation method used here was very simple, combining DMSO and hydroxyethyl starch as cryoprotectant agents. DMSO protects the cell as a chemical agent and acts by reducing electrolyte concentration in the residual unfrozen solution and around the cell at any given temperature (14). The ice crystal formation inside the cell during the freezing procedure is probably the harmful key event for the cells (13). Based on this, Massumoto et al. (15) developed a new cell cryopreservation method using a controlled rate freezing system. The cells were frozen in a controlled rate freezer chamber at the following rate: $-1^{\circ} \mathrm{C} / \mathrm{min}$ from room temperature to $-10^{\circ} \mathrm{C}$, then $-10^{\circ} \mathrm{C} / \mathrm{min}$ down to $-80^{\circ} \mathrm{C}$. All patients had marrow engraftment after infusion of these hematopoietic stem cells. The cited investigators concluded that this method could cause less damage to cells. We did not evaluate the controlled rate freezing method because our intention was to obtain karyotyping results using a simple and inexpensive freezing method.

The cell viability test showed a significant difference between the pre- and postfreezing period ( 98.8 and $78.5 \% ; \mathrm{P}<0.05$ ), as also reported by others $(4,16)$, indicating that less than $25 \%$ of the cells are lost in the freezing-thawing process. Cytogenetic analysis was successful in $52 \%$ of frozen samples $(\mathrm{P}<0.05)$ and in $76 \%$ of fresh samples $(\mathrm{P}<$ $0.05)$. Cryopreservation led to a decrease in cell viability and hence in mitotic index. Some possible explanations for this result are: 1) an inhibitory effect of DMSO on spontaneous cell proliferation as observed by Limaye (17), besides the fact that freezing is also an important insult to the cells (13), and 2) the formation of oxygen free radicals (17). Free radical damage has been implicated as one of the causes of loss of cell viability during or immediately after freezing (13). In 1997, Limaye (17) reported a new cryopreservation method in which the poor growth factor responsiveness of cryopreserved bone marrow cells was considerably restored when the cells were frozen in the presence of three antioxidants: ascorbic acid, catalase and L-tocopheryl acetate. Samples cryopreserved in the presence of these antioxidants showed a statistically significant increase in both late CFU-GM (colony-form- 
ing unit-granulocyte-macrophage) and early progenitors as compared to those cryopreserved in the absence of antioxidants. We did not use these antioxidants because our objective was to obtain the best results possible without using expensive equipment and chemicals. Nevertheless, additional studies using these antioxidants are needed.

There was a statistically significant difference in mitotic index between pre- and post-freezing A cultures $(\mathrm{P}=0.007)$ and preand post-freezing $\mathrm{B}$ cultures $(\mathrm{P}=0.000)$, confirming that mitotic index was reduced by cryopreservation (4,15-17).

In 2001, Bosga-Bouwer et al. (18) studied the results of karyotyping of fresh and defrosted bone marrow cells from 11 patients with acute myeloid leukemia. In 8 of 11 cases, the results were comparable with respect to the quality of abnormal metaphases. In the present study, whenever a comparison was possible (sufficient metaphases for analysis), chromosome morphology was similar in fresh and frozen cell cultures. We obtained good agreement of results for acute and chronic myeloid leukemia.

It is well known that the karyotype of acute myeloid leukemia cells is easier to obtain than the karyotype of acute lymphoblastic leukemia cells (2). Indeed, while myeloid cells pose few technical problems to the cytogeneticist to obtain good chromosome spreads and morphology, acute lymphoblastic leukemia cells frequently present poor spreading, fuzzy chromosomes and indistinct bands (4). In addition, it has been shown that acute lymbloblastic leukemia cells do not resist ex vivo too long, with immediate attention or a direct method being necessary to detect some abnormal clones (4). We obtained the same results in $2 / 3(67 \%)$ of our acute lymbloblastic leukemia cases before and after freezing. These results show that this cryopreservation method is feasible and reliable.

We did not find a significant difference in the proliferative effect of GM-CSF between fresh and frozen cells. In 1997, Limaye (17) reported a better response to GM-CSF when ascorbic acid, catalase and L-tocopheryl acetate were added to cryopreserved cells, while Wang et al. (19) in 2001 demonstrated that no single hematopoietic growth factor was effective when used alone for stimulating the ex vivo expansion of 50 umbilical cord blood samples. Thus, it seems that GM-CSF is not an important stimulating factor for an increase in mitotic index, as demonstrated here. We did not find a different morphological aspect of karyotype analysis with the use of GM-CSF.

Brazil is a country of continental dimensions and although hematological assistance is available in many places throughout the country, there are few places where important complementary methods such as chromosomal analysis are available. Thus, we believe that if a low-cost, feasible and reliable cryopreservation method such as that reported here were introduced as routine, samples could be sent from distant places to core facilities and hematological patients would benefit from karyotyping. The results of the present study show that cytogenetic analysis of cryopreserved bone marrow cells can be a reliable alternative to fresh cells in specific situations, notwithstanding the reduced viability and lower percent of successful analysis that are associated with freezing.

\section{References}

1. Harris NL, Jaffe ES, Diebold J et al. (1999). World Health Organization classification of neoplastic diseases of the hematopoietic and lymphoid tissues: report of the Clinical Advisory Committee Meeting - Airlie House, Virginia, November 1997. Journal of Clinical Oncology, 17: 3845-3849.
2. Haase D \& Fonatsch C (1990). Karyotype and in vitro response to GM-CSF analysis of bone marrow cultures in leukemia, myelodysplasia and aplastic anemia. Blut, 60: 192-197.

3. Haase D \& Fonatsch C (1990). Monosomy 7 provides a proliferative advantage for leukemic cells under incubation with GM-CSF in vitro. 
Blut, 61: 322-323.

4. McConnell TS, Cordova LM, Baczek NA \& Dewald GW (1990). Chromosome analysis of cryopreserved cells. Cancer Genetics and Cytogenetics, 45: 179-191.

5. Beutler E, Lichtman MA, Coller BS, Kipps TJ \& Seligsohn U (2001). Williams Hematology. 6th edn. McGraw-Hill, New York, 115-125.

6. Bennet JM, Castowsky D, Daniel MT, Flandrin G, Galton D, Gralnick M \& Sultan C (1976). Proposals for the classification of the acute leukemias. British Journal of Haematology, 33: 451-456.

7. Harris NL, Jaffe ES, Stein H \& Vardiman J (1994). Revised EuropeanAmerican Classification of Lymphoid Neoplasms: A proposal from the International Lymphoma Study Group. Blood, 84: 1361-1392.

8. Chauffaille MLLF, Yamamoto M, Odone V, Almeida MT, Maluf Jr P, Raimondi SC, Cristofani LM \& Kerbauy J (1996). A t(9;11) translocation in childhood acute mixed leukemia. São Paulo Medical Journal, 114: 1127-1130.

9. ISCN (1995). An International System for Human Cytogenetics Nomenclature. In: Mitelman F (Editor), Guidelines for Cancer Cytogenetics. Elsevier, New York, 1-56.

10. Zaroulis CG (1983). Cryopreservation of bone marrow and its clinical application. In: Glassman AB \& Umlas J (Editors), Cryopreservation of Tissue and Solid Organs for Transplantation. American Association of Blood Banks, Arlington, VA, USA, 79-90.

11. Regidor C, Garcia J \& Bornstein R (1991). Obtención y Manipulación de Precursores Hematopoyéticos. Manual de Técnicas. Ballesteros, Ibarguen, Spain, 125-127.
12. Tsuchiya H, Higuchi S \& Asou N (1990). G-CSF for chromosome analysis of myeloid leukemias and MDS. Cancer Genetics and Cytogenetics, 47: 277-279.

13. Mazur P (1970). Cryobiology: the freezing of biological systems. Science, 168: 939-949.

14. Matthes G, Hubner U, Granz M et al. (1989). Antioxidants for bone marrow cryopreservation. Folia Haematologica, 116: 451-454.

15. Massumoto CM, Mizukami S, Campos MF, Silva LA, Sakashita A \& Chamone D (1997). Cryopreservation of bone marrow and peripheral blood stem cells using a controlled rate freezing system: experience with 33 procedures. Revista da Associação Médica Brasileira, 43: 93-98.

16. Stiff PJ (1991). Simplified bone marrow cryopreservation using dimethyl sulfoxide and hydroxyethyl starch as cryoprotectants. In: Gee AP (Editor), Bone Marrow Processing and Purging - A Practical Guide. CRC Press, Boca Raton, FL, USA, 341-349.

17. Limaye LS (1997). Bone marrow cryopreservation: improved recovery due to bioantioxidant additives in the freezing solution. Stem Cells, 15: 353-358.

18. Bosga-Bouwer AG, Hendriks D, Vellenga $E$, Zorgdrager $H$ \& van den Berg E (2001). Cytogenetic analysis of cryopreserved bone marrow cells. Cancer Genetics and Cytogenetics, 124: 165-168.

19. Wang SY, Hsu ML, Huang MZ, Hsu HC, Tzeng CH \& Hung JH (2001). The activity in ex vivo expansion of cord blood myeloid progenitor cells before and after cryopreservation. Acta Haematologica, 105: 38-44. 